\title{
IMPLIKASI PARTISIPASI MASYARAKAT PADA PILKADA SERENTAK DALAM ME NINGKATKAN DEMOKRASI KONSTITUSIONAL DI INDONESIA (STUDI TERHADAP PELAKSANAAN PILKADA SERENTAK DI PROVINSI SULAWESI SELATAN TAHUN 2015)
}

\author{
Lisma ${ }^{1}$, Lita Tyesta A.L.W2 \\ Program Studi Magister Ilmu Hukum \\ Fakultas Hukum Universitas Diponegoro \\ litatyestalita@gmail.com
}

\begin{abstract}
ABSTRAK
Pemilihan Kepala Daerah sebagai salah satu praktek demokrasi Indonesia yang dijalankan di Daereh merupakan amanat konstitusi yang tertuang dalam pasal 18 ayat (4) Undang-Undang Dasar Negara Republik Indonesia Tahun. Dasar hukum itulah yang menjadi acuan pilkada yang dilakukan secara langsung dan tidak langsung namun pada kenyataan mekanisme pilkada yang dilakukan dengan langsung dan tidak langsung menyisahkan masalah, sehingga pemerintah memutuskan mereformasi sistem pilkada menjadi pilkada serentak yang rencana dilakukan dengan 7 tahap yakni 2015, 2017, 2018, 2019, 2022, 2023, 2027. Pilkada serentak tahap pertama dilaksanakan pada tahun 2015 dan salah satu daerah yang melaksanakan ialah Sulawesi selatan dengan 11 kabupaten namun partisipasi masyarakatnya belum maksimal. maka dari itu penulis merumuskan persoalan sebagai berikut yaitu : (1) Bagaimana partisipasi masyarakat pada pilkada serentak di Provinsi Sulawesi Selatan. (2) Mengapa partisipasi masyarakat pada pilkada serentak di Provinsi Sulawesi Selatan belum maksimal ?. (3) Bagaimana upaya meningkatkan partisipasi masyarakat pada pilkada serentak di masa depan di Provinsi Sulawesi Selata dalam rangka peningkatan kualitas Demokrasi Konstitusional di Indonesia ?. Penelitian ini bertujuan memberikan sumbangsi peningkatan partisipasi masyarakat pada pilkada serentak yang akan datang. Metode penelitian ini menggunakan metode pendekatan yuridis sosiologis. Penelitian hukum non doktrinal ini bersifat kualitatif karena lebih ditekankan pada pengamatan sosial di masyarakat dan kedalaman kualitas (data). Penelitian kualitatif ini diupayakan untuk memahami fenomena-fenomen di lapangan kemudian ditafsrkan dan dideskripsikan untuk menjawab tujuan penelitian. Dari analisis tersebut disimpulkan bahwa (1) partisipasi masyarakat pada pilkada serentak di Sulawesi Selatan Tahun 2015 cukup bervariasi dan tidak mengalami peningkatan signifikan bahkan mengalami penurunan (2) faktor-faktor yang menyebabkan partisipasi masyarakat belum maksimal karena faktor sosial, politik, administrasi,pendidikan, budaya dan pekerjaan serta sosialisasi yang masih sangat kurang (3) upaya meningkatkan partisipasi masyarakat dengan memperbaiki regulasi yang sudah tidak sesuai dengan konteks dan melibatkan stakeholder yang ada serta meningkatkan sosialisasi.
\end{abstract}

Kata Kunci: Demokrasi; Partisipasi Masyarakat; Pilkada Serentak; Sulawesi Selatan

\footnotetext{
${ }^{1}$ Mahasiswa Program Studi Magister IImu Hukum UNDIP

2 Penulis Kedua, Penulis Koresponden
} 


\section{A. Pendahuluan}

Masalah Demokrasi merupakan suatu pola pemerintahan yang mengikut sertakan secara aktif semua anggota masyarakat dalam keputusan yang diambil oleh mereka yang diberi wewenang. Maka legitimasi pemerintah adalah kemauan rakyat yang memilih dan mengontrolnya. Rakyat memilih wakilwakilnya dengan bebas dan melalui mereka ini pemerintahnya. Disamping itu, dalam Negara dengan penduduk jutaan, para warga negara mengambil bagian juga dalam pemer intahan melalui persetujuan dan kritik yang dapat diutarakan dengan bebas dalam media massa.

Salah satu wujud dan mekanisme demokrasi di daerah adalah pelaksanaan pemilihan kepala daerah secara langsung. Pilkada merupakan sarana manifestasi kedaulatan dan pengukuhan bahwa pemilih adalah masyarakat di daerah. Pertama, memilih kepala daerah sesuai dengan kehendak bersama masyarakat di daerah sehingga ia diharapkan dapat memahami dan mewujudkan kehendak masyrakat di daerah. Kedua, melalui pilkada diharapkan pilihan masyarakat di daerah didasarkan pada misi, visi, program serta kualitas dan integrasi calon kepala daerah yang sangat menentukan keberhasilan penyelenggaraan pemerintahan di daerah. Ketiga pilkada merupakan sarana pertanggungjawaban sekaligus sarana evaluasi dan kontrol publik secara politik terhadap seorang kepala daerah dan kekuatan politik yang menopang. $^{3}$

Dinamika perkembangan dan peningkatan kualitas Demokrasi di Idnonesia dapat kita pahami dengan melakukan analisis terhada teorip Linz dan Stepan dalam buku problem of democratic transition and consolidation menyebut lima persyaratan agar konsolidasi demokrasi demokrasi berhasil. Pertama, adanya masyarakat sipil yang otonom dan jaminan hukum kebebasan berserikat dan menyatakan pendapat: kedua, adanya masyrakat politik yang diberi kesempatan untuk bersaing secara sehat untuk mengontrol dan mnjalankan kekuasaan: ketiga, dianutnya ideologi supremasi hukum; keempat adanya birokrasi yang legal-rasional dan kelima terciptanya masyarakat ekonomi yang menjadi perantara antara negara dan masrakat. 4

Pelaksanaan pilkada yang dilakukan secara langsung maupun tidak langsung dengan dipilih oleh DPRD harus tunduk pada ketentuan konstitusi sebagai upaya mewujudkan demokrasi konstitusional dalam memilih pemimpin pada level daerah seperti gubernur, bupati dan wali kota. Pasal 18 ayat 4 UUD NRI 1945 menyatakan bahwa gubernur, bupati, dan wali kota dipih secara demokratis. Makna dari Pasal 18 ayat (4) UndangUndang Dasar Negara Republik Indonesia Tahun

\footnotetext{
3 Janedjri M Gaffar, Politik Hukum Pemilu, (Jakarta: Konpress, 2012), hlm 85

4 Janedjii M Gaffar, Loc. Cit, hlm. 86
} 
1945 ialah bahwa ketentuan tersebut mengandung arti bahwa pemilihan itu harus dilakukan dengan cara yang demokratis, yang menjamin prinsip kedaulatan rakyat, seperti dipilih secara langsung atau cara lain sesuai dengan keistemewaan atau kekhususan daerah yang diatur dengan undangundang seperti penunjukan kepala daerah pada daerah-daerah istimewa yakni Daerah Istimewa Yogyakarta yang melakukan mekanisme penunjukan kepala daerah namun tetap dianggap demokratis oleh masyarakat setempat, begitupun dengan Aceh dan Papua. Frase kata "dipilih secara demokratis" diartikan dapat dipilih oleh anggota DPRD dan dapat pula dipilih langsung oleh rakyat dalam suatu pemilihan kepala daerah. Pelaksanaan pilkada secara demokratis sebagaimana yang termaktub dalam konstitusi tersebut didasarkan secara fleksibel dengan menyesuaikan kondisi daerah tertentu apakah dilakukan secara langsung maupun tidak langsung melalui DPRD.

Pelaksanaan pilkada secara langsung tersebut dianggap tidak efektif karena sejumlah faktor seperti ketidak efektifan anggaran, regulasi,waktu persiapan, dan money politik. Upaya lain yang dilaksanakan pada pemilukada sebelumnya adalah menggati model pemilihan kepala daerah secara tidak langsung yang dipilh oleh DPRD, akan tetapi pemilihan kepala daerah oleh DPRD juga menuai persoalan,pasalnya tidak merepresentasikan makna pemilihan secara demokratis, artinya kedaulatan tertinggi berada ditangan rakayat sehingga pemilihan harus dilaksanakan secara langsung. Implikasi dari persoalan pilkada langsung yang telah berlangsung secara tidak efektif terutama untuk menghemat anggaran maka disusunlah pelaksanaan pilkada serentak yang merupakan salah satu inovasi yang diusulkan sebagai penguatan demokrasi lokal dan dilaksanakan berdasarkan pada kondisi sosial, politik, budaya dan geografis daerah setempat. Pelaksanaan pilkada serentak yang telah digagas oleh DPR melalui pembentukan Rancangan Undang-Undang Pemilihan Umum Kepala Daerah secara Serentak yang pelaksanaanya berlangsung pada tiga tahap yakni 2015, 2017 dan 2019.

Pilkada serentak telah dilaksanakan tahap pertama pada tahun 2015 akhir, keberhasilan dan kualitas pelaksanaan pilkada ditentukan oleh persiapan tahapan pilkada serentak dilaksanakan secara konsisten sesuai dengan peraturan perundang-undangan. Beberapa persoalan yang menganggu dan merisaukan pelaksanaan pilkada serentak tahap pertama ialah rendahnya partisipasi publik (partisipasi pemilih).

Provinsi Sulawesi Selatan dengan ibu kota Makassar telah melaksanakan pilkada serentak tahap peratama pada desember 2015, beberapa daerah yang melaksanakan pilkada serentak pada tahap pertama diikuti 10 daerah yakni Gowa, 
Toraja, Lutim,Lutra, Selayar, Bulukumba, Maros, Pangkep, Barru dan Soppeng.

Namun pada pelaksanaan pilkada serentak tahap pertama akhir tahun 2015 masih belum berhasil secara maksimal, hal tersebut dapat dilihat dalam tidak tercapainya batas nominal partisipasi publik seperti yang ditetapkan oleh KPU pusat yakni $75 \%$ partisipasi dalam pilkada yang dilaksankan di Provinsi sulawesi selatan. Partisipasi publik dalam pilkada serentak di Provinsi Sulawesi selatan hanya sekitar 2,5 persen dalam setahun dan hanya gowa naik 10 persen serta kabupaten selayar dengan capaian 83 persen dari jumlah DPT 90.668 orang . 11 kabupaten di sulsel melaksanakan pilkada dan partisipasi publik (pemilih) tidak lebih dari 2,5 persen. Informasi di Kabupaten Bulukumba ada 81 ribu c6 atau undangan tidak tersebar dan dua daerah Luwu Utara dan Soppen partisipasi menurun pada pilkada serentak tahan pertama 2015. Pilkada di Kabupaten Tana Toraja, 40 ribu dari 167.765 pemilih yang terdaftar dalam daftar pemilih tetap (DPT) di Kabupaten Toraja Utara tidak mencoblos saat pemilihan bupati. Dugaan partisipasi publik pada pilkada serentak menurun karena banyak perantau yang tidak pulang ke kampung halamanya.

Sejumlah kendala yang dihadapai pada pelaksanaan pilkada serentak 2015 di Sulawesi Selatan berupa persoalan teknis, waktu yang sangat singkat untuk melakukan kampanye hanya 3 bulan, persoalan regulasi oleh PKPU yang bisa memberikan suvenir seharga 25 ribu perorang merupakan suatu permainan money, belum lagi masalah distribusi logistik kampanye yang sangat terbatas, netralitas PNS dalam pemilihan yang berakibat pada keberlangsungan para PNS dalam pekerjaanya. Berbagai persoalan di atas sekiranya menjadi evaluasi dalam pelaksanaan pilkada pada tahap ke dua masa yang datang.

Namun dari pelaksanaan pilkada tahap pertama di Sulsel mengalami penurunan. Banyak pertanyaan dibenak yang harus dipecahkan terkait rendahnya partisipasi masyarakt dalam pilkada padahal dalam konteks negara Indonesia yang menganut paham Demokrasi Konstitusional dapat dinilai berjalan dan meningkat apabila masyarakat dapat berpartisipasi dalam ruang publik sperti kebebasan menyatakan pendapat dan ikut serta dalam pemilihan kepala daerah. Beranjak dari polemik pelaksanaan pilkada di Sulsel yang mengalami penurunan partisipasi oleh masyarakat maka penulis merumuskan masalah sebagai berikut: Pertama: Bagaimana partisipasi masyarakat pada pilkada serentak di Provinsi Sulawesi Selatan Tahun 2015 ?. Kedua: Mengapa partisipasi masyarakat pada pilkada serentak di Provinsi Sulawesi Selatan belum maksimall ?.Ketiga: Bagaimana upaya meningkatkan partisipasi masyarakat pada pilkada serentak 
Jurnal Law Reform

Volume 13, Nomor 1, Tahun 2017
Program Studi Magister Ilmu Hukum

Fakultas Hukum Universitas Diponegoro dimasa depan di Provinsi Sulawesi Selatan dalam

rangka peningkatan kualitas Demokrasi

Konstitusional di Indonesia?

\section{B. Kerangka Teori}

Teori hukum yang penulis gunakan dalam penelitian ini adalah teori demokrasi konstitusional sebagai hasil dari reformasi bahwa pelaksanaan sistem ketatanegaraan Indonesia berdasarkan atas hukum tidak hanya kekuasaan. Penulis juga menggunakan teori sistem hukum yang mana setiap elemen-elemen sistem hukum yakni substansi, struktur dan kultur hukum saling bekerja sehingga dapat mempengaruhi tingkat partisipasi masyarakat dalam pemilu. Selain itu, teori bekerjanya hukum dapat kita gunakan untuk menganalisis bagaimana bekerjanya regulasiregulasi dalam masyarakat apa saja yang mempengaruhi dan menghambat peningkatan partisipasi masyarakat dala pilkada ketika regulasi tersebut diterapkan dalam masyarakat.

Menurut pendapat Gaventa dan Valderna dalam bukunya Dr. Siti Irene Astuti Dwiningrum menegaskan bahwa partisipasi publik (masyarakat) telah mengalihkan konsep partisipasi menuju suatu kepedulian dengan berbagai bentuk keikutsertaan warga dalam pembuatan kebijaksanaan dan pengambilkan keputusan di berbagai gelanggan kunci yang mempengaruhi kehidupan warga masyarakat. ${ }^{5}$ Partisipasi publik (masyarakat) menjadi salah satu indikator dalam penerapan demokratisasi di Indonesia, partisipasi publik pada pilkada serentak sebagai salah satu ciri negara demokrasi menjadi hal yang sangat urgen untuk dipenuhi karena tingkat partisipasi publik menjadi devenden variabel dalam meningkatkan kualitas demokrasi di Indonesia khususnya demokrasi konstitusional. Tingkat partisipasi publik pada pemilihan umum maupun pilkada serentak dipengaruhi oleh berbagai faktor, diantaranya ${ }^{6}$ : partisipasi politik, keragaman pemilih, penyelenggara pemilu, Kepuasan publik pada pemerintah dan sistem pemilu dan figur calon.

\section{Metode penelitian}

Metode penelitian yang digunakan dalam penelitian ini adalah yuridis sosiologis, pendekatan yuridis sosiologis bermaksud melakukan penjelasan atas permasalah yang diteliti dalam hubunganya dengan aspek-aspek hukum serta mencoba menjelajahi realitas empiris dalam masyarakat. Hukum tidak hanya dilihat sebagai suatu entitas normatif yang mandiri atau teoritik, melainkan juga dilihat sebagai bagian riil dari sistem sosial berkaitan denga variabel sosial yang lain.

\footnotetext{
${ }^{5}$ Siti Irene Astuti Dwiningrum, Desentralisasi dan Partisipasi Masyarakat dalam Pendidikan, (Yogyakarta: Pustaka Pelajar , 2015), hlm. 54

6 Soewoto Mulyosudarsono, Pembaharuan Ketatanegaraan melalui Perubahan Konstitusi, (Malang: Asosiasi Pengajar HTN dan HAN Jawa Timur, 2004), hlm. 354-355
} 
Penelitian ini bersifat deskriftif analitis. Deskriptif yaitu. Penelitian menggunakan survei lapangan. 7 Sedangkan analitis dilakukan dengan adanya suatu analisa terhadap permasalahan yang telah dikemukakan di muka dengan menggunakan peraturan perundang-undangan yang berlaku, pendapat para ahli, dan teori-teori ilmu hukum yang berkaitan dengan penelitian ini.

Penelitian ini menggunakan 2 jenis data yakni data primer dan data sekunder. Pertama: Data primer ialah hasil wawancara dan data yang berkaitan dengan penelitian. Wawancara dilakukan pada beberapa pihak yakni: 1) Pihak Komisi Pemilihan Umum Provinsi Sulawesi Selatan, 2) Masyarakat Kabupaten Gowa, Maros, Bulukumba, Toraja Utara dan Luwu Timur Povinsi Sulawesi Selatan. Kedua: data sekunder adalah data yang sudah dalam bentuk jadi, seperti data dalam dokumen dan publikasi. ${ }^{8}$ Data sekunder meliputi: 1) bahan hukum primer berupa: (UUD RI Tahun 1945, UU No 8 Tahun 2015 tentang perubahan penetapan peraturan pemerintah pengganti UU Nomor 1 Tahun 2014 tentang Pemilihan Gubernur, Bupati dan Walikota, UU No 10 Tahun 2016 tentang Perubahan Kedua atas Undang-Undang Nomor 1 Tahun 2015 tentang Penetapan Peraturan

7 Altherton \& Klemmack (Irawan Soehartono), Metode Penelitian Sosial - Suatu Tehnik Penelitian Bidang Kesejahteraan Sosial Lainnya, (Bandung: Remaja Rosda Karya, 1999), hlm. 63

8 Rianto Adi, Metode penelitian sosial dan hukum, (Jakarta:Granit, 2010), hlm. 57
Pengganti Undang-Undang Nomor 1 Tahun 2014 tentang Pemilihan Gubernur, Bupati, dan Walikota menjadi Undang-Undang, Peraturan Komisi Pemilihan Umum Nomor 5 Tahun 2015 tentang Sosialisasi dan Partisipasi Masyarakat dalam Pemilihan Gubernur dan Wakil Gubernur, Bupati dan Wakil Bupati, dan/atau Walikota dan Wakil Walikota, Peraturan Komisi Pemilihan Umum Nomor 4 Tahun 2015 tentang Pemutakhiran Data dan Daftar Pemilih dalam Pemilihan Gubernur dan Wakil Gubernur, Bupati dan Wakil Bupati, dan atau Walikota dan Wakil Walikota.). 2) Bahan hukum sekunder berupa dasar-dasar teoritik yang relevan. 3) Bahan hukum tertier berupa bahan hukum dari kamus, ensiklopedia, artikel, jurnal dan koran.

Penelitian ini menggunakan metode analisis kualitatif, analisis data kualitatif ialah menguraikan data secara bermutu dalam kalimat teratur, runtun, logis, tidak tumpang tindih dan efektif sehingga memudahkan interpretasi data dan pemahaman hasil analisis.

\section{Hasil penelitian dan pembahasan}

\section{Partisipasi masyarakat pada pilkada serentak di Provinsi Sulawesi Selatan tahun 2015}

Pilkada serentak merupakan reformasi sistem pemilihan kepala daerah karena menyisahkan persoalan berupa tingginya ongkos demokrasi maka hadirnya pilkada serentak 
Jurnal Law Reform

Volume 13, Nomor 1, Tahun 2017
Program Studi Magister Ilmu Hukum

Fakultas Hukum Universitas Diponegoro menghemat anggaran dan dan mengefisiensi waktu. Persoalan-persoala dalam pilkada serentak tersebut tentu akan berimplikasi pada partisipasi masyrakat dalam pilkada, jika pada pilkada sebelumnya yakni pilkada langsung yang dilaksanakan setiap 5 tahun. Disamping itu pemilihan legislatif dan eksekutif yang juga menyita waktu yang banyak akan membuat masyarakat merasa jenuh untuk ikut berpartisipasi karena setiap kali harus mendatangi TPS untuk mencoblos. Persoalan anggaran juga sangat berdampak karena negara akan mengeluarkan biaya yang bersar untuk menugaskan perangkatperangkat daerah dalam mensosialisasikan dan mendata masyarakat di setiap daerah. Dengan reformasi sistem pilkada serentak diharapkan akan memberikan pengaruh pada partisipasi masyarakat karena masyarakat tidak perlu sering ke TPS lagi dan meninggalkan aktivitasnya yang sangat penting atau jika berada diperantaun tidak perlu lagi bolakbalik ke daerah untuk mencoblos lagi.

Seperti yang dijelaskan oleh Ketua KPU Provinsi Sulawesi Selatan bahwa agenda pilkada serentak merupakan keputusan politik oleh penguasa dalam menjalankan proses demokratisasi di Negara Indonesia. Pilkada serentak yang dicetuskan pemerintah disambut baik oleh Provinsi Sulawesi Selatan, implikasi positif yang dirasakan oleh penyelenggara yaitu menekan konflik-konflik horizontal dan gesekan- gesekan dalam masyarakat seperti yang terjadi pada pilkada langsung sebelumnya, intinya pilkada serentak efisien dan efektif untuk dilaksanakan. ${ }^{9}$

Partisipasi masyarakat di Provinsi Sulawesi Selatan dilatarbelakangi oleh alasan-alasan yang berbeda, Keterlibatan masyarakat dalam proses demokrasi di daerah tidak bisa dipungikiri adanya kepentingan-kepentingan tertentu, tipe masyarakat juga menentukan sikapnya terhadap kegiatan pemerintahan. Ada yang apatis, kritis dan memeiliki kesadaran politik yang tinggi.

Provinsi Sulawesi Selatan telah melaksanakan pilkada serentak tahap awal pada desember tahun 2015 yang dilaksanakan oleh 11 kabupaten, berikut ini data partisipasi masyarakat (pemilih) pada pilkada serentak 2015, yakni:

\begin{tabular}{|l|l|l|l|}
\hline No & Kabupaten & $\begin{array}{l}\text { Pilkada } \\
2010\end{array}$ & $\begin{array}{l}\text { Pilkada } \\
\text { Serentak } \\
2015\end{array}$ \\
\hline 1 & Kep. Selayar & 82.28 & 81.22 \\
\hline $\mathbf{2}$ & Bulukumba & $\mathbf{6 8 . 4 2}$ & $\mathbf{5 8 . 9 2}$ \\
\hline $\mathbf{3}$ & Gowa & $\mathbf{7 4 . 7 1}$ & $\mathbf{6 7 . 7 5}$ \\
\hline 4 & $\begin{array}{l}\text { Pangkajene } \\
\text { dan Kep }\end{array}$ & 78.28 & 72.21 \\
\hline $\mathbf{5}$ & Maros & $\mathbf{7 5 . 2 0}$ & $\mathbf{6 1 . 5 1}$ \\
\hline
\end{tabular}

\footnotetext{
${ }^{9}$ Wawancara bersama DR. Ikbal Latief SH.M.Hum (Ketua KPU Provinsi Sulawesi Selatan) 19 Desember 2016
} 
Jurnal Law Reform

Volume 13, Nomor 1, Tahun 2017

\begin{tabular}{|l|l|l|l|}
\hline 6 & Barru & 77.88 & 77.53 \\
\hline 7 & Soppeng & 76.21 & 77.75 \\
\hline 8 & Tana Toraja & 78.87 & 71.82 \\
\hline $\mathbf{9}$ & Toraja Utara & $\mathbf{7 4 . 7 8}$ & $\mathbf{7 2 . 0 6}$ \\
\hline 10 & Luwu Utara & 78.27 & 76.43 \\
\hline $\mathbf{1 1}$ & Luwu Timur & $\mathbf{7 1 . 3 0}$ & $\mathbf{6 9 . 3 2}$ \\
\hline
\end{tabular}

Sumber: KPU Provinsi Sulawesi Selatan

Data tersebut menunjukan sejumlah daerah memiliki keragaman tingkat partisipasi yang bervariasi, ada yang meningkat, bahkan rata-rata mengalami penurunan. Misalnya bulukumba, tingkat partisipasinya menurun sejak 2010 hingga 2015 begitupun dengan maros, Gowa dan Luwu Timur serta Toraja utara. Pilkada serentak yang dilaksanakan pada tahun 2015 ini merupakan inovasi positif pemerintah untuk melakukan efisiensi waktu dan anggaran dibandingkan dengan pilkada langsung ditahun-tahun sebelumnya.

\section{Faktor-faktor yang mempengaruhi partisipasi} masyarakat pada pilkada serentak belum maksimal di Provinsi Sulawesi Selatan tahun 2015

Menurut Bisma Arianto bahwa alasan rendahnya partisipasi masyarakat untuk memiih diklasifikasikan menjadi 2 hal yakni faktor internal dan faktor eksternal, faktor-faktor tersebut adalah sebagai berikut: 10

1. Faktor Internal

Faktor internal yakni:

a. Faktor Teknis: adanya kendala yang bersifat teknis yang dialami oleh pemilih sehingga menghalanginya untuk menggunakan hak pilihnya. Seperti saat hari pecoblosan pemilih sedang sakit, pemilih sedang ada kegiatan yang lain serta berbagai hal lainya yang sifatnya menyangkut pribadi pemilih. kondisi itulah yang secara teknis membuat pemilih tidak datang ke TPS untuk menggunakan hak pilihnya.

b. Faktor Pekerjaan: Faktor pekerjaan juga merupakan hal yang sangat mendasar pengaruhnya pada partisipasi masyarakat di Sulawesi Selatan, beberapa daerah seperti Toraja Utara, Luwu Timur, Bulukumba, Maros, dan Gowa tidak memilih karena merantau di luar daerah untuk pekerjaan.

Seperti di Toraja Utara menurut keterangan salah satu responden:

Tingkat golput yang terjadi di toraja utara bukanji karena apa, tapi banyak memang yang merantau. Apalagi di Toraja

\footnotetext{
${ }^{10}$ Fadli Ramadhanil, Desain Partisipasi Masyarakat dalam Pemantauan Pemilihan Umum, (Jakarta: Perludem,2015), hlm. 40
} 
Jurnal Law Reform

Volume 13, Nomor 1, Tahun 2017
Program Studi Magister Ilmu Hukum

Fakultas Hukum Universitas Diponegoro kan lebih banyak pertanian sama ternak, dan itu tidak cukup untuk kesejahteraanya makanya banyak yang ke luar daerah cari pekerjaan terus tidak balik waktu pemilihan.

begitupun dengan Luwu Timur:

partisipasi pemilih tahun 2015 menurun sekitar 5 a atau penurunanya kurang lebih 1.497 .000 menjadi 1.200 .000 karena tingkat apatis masyarakat setempat dan juga banyak masyarakat yang berprofesi sebagai penjual sering ke luar daerah.

\section{Faktor Eksternal}

Faktor eksternal meliputi 5 yakni:

a. Faktor Administratif: Faktor berikut yang menjadi penghalang dari aspek administrasi adalah permasalahan kartu identitas. Masih ada masyarakat tidak memiliki KTP. Jika masyarakat tidak memiliki KTP maka tidak akan terdaftar di DPT (Daftar Pemilih Tetap) karena secara administratif KTP yang menjadi rujukan dalam mendata dan membuat DPT. Maka masyarakat baru bisa terdaftar sebagai pemilih menimal sudah tinggal 6 bulan di satu tempat.

Seperti yang terjadi di Toraja Utara :

Ada bebrapa orang di daerahku tidak bisaki mencoblos karena tidak ada surat panggilanya, nabawami kartu keluarganya sama KTPnya tetap juga tidak dibolehkan mencoblos. ${ }^{11}$

b. Faktor Sosialisasi: Persoalan yang paling krusial dari sosialisasi yang terjadi di beberapa daerah ialah persoalan sosialisasi, menurut Ketua KPU Provinsi Sulawesi Selatan :

Kendala yang terasa pada saat pilkada serentak ialah kurangya anggaran untuk sosialisasi, pengajuan anggaran kepada Pemerintah Daerah tidak sesuai sehingga KPU sendiri mengalami kesulitan dalam memasifkan sosialisasi. ${ }^{12}$

C. Faktor Pendidikan: Faktor pendidikan cukup mempengaruhi dengan kuat belum maksimalnya partisipasi masyarakat karena tingkat pendidikan pemilih akan mempengaruhi cara pandang terhadap keterlibatanya dalam pemilihan kepala daerah.

d. Faktor Figuritas: Faktor figuritas ini kuat mempengaruhi partispasi masyarakat pada pilkada serentak bahkan meskipun pada pilkada sebelumnya, seperti yang terjadi di Kabupaten Gowa yang sebenarnya masih merupakan daerah kerajaan namun ada calon kepala daerah yang mencalonkan diri beberapa kali namun tetap tidak menang

\footnotetext{
${ }^{11}$ Wawancara bersama Wiwin (Masyarakat Kabupaten Toraja Utara Kota Rantepao) 2 Januari 2017

12 Wawancara bersama Dr.lqbal Latief, SH.M.Hum (Ketua KPU Provinsi Sulawesi Selatan) 9 Januari 2017
} 
Jurnal Law Reform

Volume 13, Nomor 1, Tahun 2017
Program Studi Magister Ilmu Hukum

Fakultas Hukum Universitas Diponegoro dalam setiap pilkada hal ini dikarenakan ada sosok figuritas yang telah dikenal dalam masyarakat Kabupaten Gowa sendiri yang telah berasal dari keturunan mantan kepala daerah sebelumnya dari beberapa periode yang telah dikenal dengan kuat oleh masyarakat setempat.

e. Faktor politik: Faktor politik adalah alasan atau penyebab yang ditimbulkan oleh aspek politik masyarakat tidak mau memilih. Seperti ketidakpercayaan dengan partai, tak punya pilihan dari kandidat yang tersedia atau tidak percaya bahwa pemilu ataupun pilkada akan membawa perubahan dan perbaikan.

\section{Upaya meningkatkan partisipasi masyarakat} pada pilkada serentak di Provinsi Sulawesi

\section{Selatan}

Ada beberapa rencana strategis sebagai upaya meningkatkan partisipasi masyarakat dalam pilkada, yaitu:

a. Memetakan dan menguatkan partisipan: Kelompok pemilih, kelompok sadar politik sebagai mitra strategis

b. Penyampaian informasi yang efektif

c. Panwaslu sebagai fasilitator

d. Model pelibatan dan partisipasi masyarakat

e. Pengawasan semesta dan penyediaan teknologi informasi untuk memudahkan pelaporan

f. Duta pengawasan dan democracy heroes g. Kerjasama dengan pemantau dan pembentukan paralegal

h. Internalisasi partisipasi dalam pengawasan pemilu.

\section{E. Simpulan dan Saran}

\section{a. Simpulan}

1) Partisipasi Masyarakat Pada Pilkada Serentak 2015 di Provinsi Sulawesi Selatan cukup bervariasi bahkan pilkada serentak tahap pertama ini tidak memberikan pengaruh signifikan terhadap peningkatan partisipasi masyarakat selain itu ada 6 daerah yang menjadi objek penelitian penulis yakni daerah yang tingkat partisipasi masyarakat rendah bahkan menurun ialah Bulukumba, Toraja Utara, d Maros Gowa dan Luwu Timur. Penurunan partisipasi masyarakat pada pilkada serentak ini dipengaruhi oleh banyak faktor namun yang dapat kita analisa bahwa sebenarnya persepsi masyarakat terhadap pilkada serentak tidak ada perbedaan dan pengaruhnya bahkan dianggap sama dengan pilkada sebelumnya sehingga partisipasi masyarakat tidak memberikan pengaruh pada pilkada serentak 2015 ini

2) Faktor-faktor yang mempengaruhi tingkat partisipasi masyarakat yang belum maksimal pada pilkada serentak di Sulawesi Selatan Tahun 2015 ialah faktor sosial, budaya, politik, adminsitrasi dan pekerjaan. Faktor-faktor 
tersebut sangat besar perananya dalam mengukur maksimal atau tidak maksimalnya partisipasi masyarakat. Misalnya faktor administrasi karena persoalan tidak memiliki surat panggilan dan tidak terdaftar dalam DPT daerah setempat, faktor pekerjaan dan faktor politik yang signifikan pengaruhnya karena kepentingan plitik pragmatis dan transaksional membuat masyarakat menjadi apatis dan jenuh untuk ikut berpartisipasi.

3) Upaya-upaya meningkatkan partisipasi masyarakat dapat dilakukan dengan perubahan regulasi. Terbukanya secara luas bagi masyarakat yang ingin bergabung dalam PPK,PPS, dan KPPS, penguatan kegiatan berbasis masyarakat seperti jejak pendapat, duta demokrasi. keterlibatan stake holder untuk memberikan pendidikan politik bagi masyarakat, KPU sebagai mitra masyarakat telah menyediakan rumah pintar pemilu dan komunitas pemilu yang dapat menghimpun masyarakat yang termarginalkan yaitu perempuan dan kaum disabiltas. Perguruan Tinggi bekerjasama dengan Pemerintah Daerah beserta LSM/Ormas dan Orpol membuat program kerja untuk berpartisipasi pada pilkada serentak 2017. Pada dasarnya partisipasi masyarakat di setiap daerah terletak bagaimana upaya kreativitas Pemda beserta pemerintah dan masyarakat dalam meningkatkan partisipasi masyarakat.

\section{b. Saran}

1) Berharap agar regulasi baik Undang-Undang maupun Perataturan Komisi Pemilihan Umum dapat disesuaikan dan diimplementasikan dengan baik oleh pemerintah beserta jajaranya agar partisipasi masyarakat dapat lebih meningkat dalam pilkada serentak yang akan digelar 6 tahapan yang akan datang.

2) Membangun relasi yang kuat antara Pemerintah dan stakeholder lainya dalam pilkada serentak yang akan datang agar tidak tercipta sekat antara pemerintah dan masyarakat sehingga bersikap tidak apatis.

3) Semua pihak perlu bekerjasama demi terwujudnya Demokrasi yang berlandaskan atas hukum di level pusat maupun daerah melalui partisipasi dalam pilkada serentak agar dapat membangun daerah dan menguatkan otonomi daerah demi peningkatan kesejahteraan rakyat.

\section{Daftar Pustaka}

Altherton \& Klemmack (Irawan Soehartono), 1999, Metode Penelitian Sosial - Suatu Tehnik Penelitian Bidang Kesejahteraan Sosial Lainnya, Bandung: Remaja Rosda Karya.

Janedjri M Gaffar, 2012, Politik Hukum Pemilu, Jakarta: Konpress. 
Fadli Ramadhanil, 2015, Desain Partisipasi Masyarakat dalam Pemantauan Pemilihan Umum, Jakarta: Perludem.

Siti Irene Astuti Dwiningrum, 2015, Desentralisasi dan Partisipasi Masyarakat dalam Pendidikan, Yogyakarta: Pustaka Pelajar.

Soewoto Mulyosudarsono, 2004, Pembaharuan Ketatanegaraan melalui Perubahan Konstitusi, Malang: Asosiasi Pengajar HTN dan HAN Jawa Timur

Rianto, Adi, 2010, Metode Penelitian Sosial dan Hukum, Jakarta: Grani.

Wawancara bersama DR. Ikbal Latief SH.M.Hum (Ketua KPU Provinsi Sulawesi Selatan) 19 Desember 2016

Wawancara bersama Dr.lqbal Latief, SH.M.Hum (Ketua KPU Provinsi Sulawesi Selatan) 9 Januari 2017 